\title{
Wpływy polityczne w samorządzie gmin wiejskich województwa kieleckiego w latach 1918-1939
}

\author{
Political Influence in the Self-Government of Rural Communes \\ of the Kielce Province in the Years 1918-1939
}

\section{- Abstrakt •}

Po 1918 r. mieszkańcy wsi stanowili większość obywateli odrodzonego państwa i od ich postawy politycznej zależało powodzenie budowy skonsolidowanego społeczeństwa obywatelskiego. Występujące wówczas w środowisku wiejskim antagonizmy społeczne, ekonomiczne i narodowościowe, jak również słaby stopień identyfikacji chłopów z odrodzonym państwem polskim nie ułatwiały tego zadania. Przyjęte rozwiązania ustrojowo-prawne, w tym powołanie samorządu gminnego, jak i zapowiedź reformy rolnej, miały politycznie i materialnie związać mieszkańców wsi z państwem polskim. Środowisko wiejskie na ogół pozytywnie odniosło się do kształtu powołanego samorządu gminnego, tym bardziej że w województwie kieleckim istniała już tradycja gminy zbiorowej.

Słowa kluczowe: samorząd; radni; partia polityczna; gmina; wieś; wybory

\section{- Abstract}

After 1918, country dwellers comprised majority of citizens of the revived Poland and a success of construction of the consolidated civil society depended on their political conduct. Social, economic and ethnic antagonisms appearing in the countryside as well as the weak degree of identification of peasants from the revival with the Polish state did not facilitate this task. Accepted political and legal solutions, including appointing the commune self-government as well as the announcement of the agricultural reform, were supposed to politically and financially connect the country dwellers with the Polish state. The country environment in general positively referred to the shape of the appointed commune self-government, all the more that a tradition of the collective commune had already existed in the Kielce province.

Keywords: self-government; councilors; political parties; commune; village; elections 
Po odzyskaniu niepodległości przez Polskę w 1918 r. mieszkańcy wsi stanowili tu większość obywateli i w dużej mierze od ich politycznych postaw zależało powodzenie budowy skonsolidowanego społeczeństwa obywatelskiego. Zadania tego nie ułatwiały dostrzegalne wówczas w środowisku wiejskim antagonizmy społeczne, ekonomiczne i narodowościowe oraz słaby stopień identyfikacji chłopów z odradzającym się państwem. Przyjęte rozwiązania ustrojowo-prawne, m.in. powołanie samorządu gminnego oraz zapowiedź reformy rolnej, politycznie i materialnie wiązały mieszkańców wsi z państwem polskim. Nowy kształt powołanego samorządu gminnego spotkał się na ogół z aprobatą środowisk wiejskich. Postawa ta nie dziwi, gdyż np. w województwie kieleckim istniała już tradycja gminy zbiorowej. Samorząd gminny stał się także miejscem walki politycznej ugrupowań, których działalność była ukierunkowana na środowisko wiejskie: Polskiego Stronnictwa Ludowego (PSL) „Piast”, PSL „Wyzwolenie”, jak i takich ugrupowań jak np. Związek Ludowo-Narodowy (ZLN) czy Polska Partia Socjalistyczna (PPS) (Brodowska, 1989, s. 433-434, 441-448).

Artykuł Wptywy polityczne w samorządzie gmin wiejskich województwa kieleckiego w latach 1918-1939 powstał przede wszystkim w oparciu o źródła archiwalne zdeponowane w Archiwum Państwowym w Kielcach, w zespołach Urzędu Wojewódzkiego Kieleckiego I (APK UWK I) oraz Starostwa Powiatowego Kieleckiego (SPK), w Archiwum Państwowym w Katowicach (APKat), w zespołach Starostwa Powiatowego Zawierciańskiego (SPZaw) i Starostwa Powiatowego Olkuskiego (SPOlk), oraz w Archiwum Państwowym w Częstochowie (APCz), w zespole Starostwa Powiatowego Częstochowskiego (SPCz).

W artykule autor zastosował metodę empiryczną, skupioną na analizie wpływu ówczesnej sytuacji politycznej na skład reprezentacji samorządowej lokalnej społeczności. Ważne jest pytanie o konsekwencje przyjętych wysokich standardów demokratycznych po 1918 r. wyrażających się m.in. w upodmiotowieniu społeczności lokalnych wobec zapóźnienia cywilizacyjnego ziem polskich byłego zaboru rosyjskiego.

Dokładna analiza wpływów i sympatii politycznych w gminach wiejskich województwa kieleckiego w latach 1918-1939 nastręcza wiele problemów, m.in. z powodu stanu bazy źródłowej dotyczącej życia politycznego gmin wiejskich. Zachowane dokumenty w większości są niekompletne, dowolnie i niestarannie sporządzone. Wątpliwości budzi określenie stopienia wpływu uregulowań prawnych, jak np. ordynacji wyborczej i oddziaływania państwa na działalność oraz kształt polityczny samorządu gminnego. Trudny jest do określenia wpływ specyfiki danego środowiska wiejskiego na preferencje wyborcze i stosunek do instytucji samorządowych. Mieszkańcy wsi oddawali swoje głosy, kierując się często uznaniem dla danej oso- 
by, a nie jej przynależnością partyjną. Problem dotyczy także określenia sympatii politycznych wybieranych stosunkowo często tzw. bezpartyjnych. Stąd wszelkie uogólnienia mogą budzić uzasadnione wątpliwości. Najtrudniejsze jest określenie stopnia aktywności politycznej mieszkańców wsi, gdzie na uwagę autora zasługuje teza mówiąca o zaangażowaniu w działalność samorządową nielicznego grona działaczy partyjnych, inteligencji i ziemiaństwa, a bierności pozostałej, zdecydowanie większej części społeczności gminnej (Przeniosło, 2009, s. 172-173).

Niektóre z powyższych problemów zostały poruszone m.in. przez Mieczysława B. Markowskiego w artykule Samorzad terytorialny w Pinczowie do 1939 roku (Markowski, 1999). Autor artykułu zwrócił uwagę, że pierwsze wybory w granicach powiatu pińczowskiego do rad gminnych i wójtów odbyły się w 1919 r. we wszystkich gminach. Zachowany spis radnych gminnych, ich zastępców, wójtów i podwójcich (zastępców wójtów) nie zawiera składu zawodowego radnych, ani przynależności partyjnej. W kolejnych wyborach w 1927 r. na 360 radnych wybranych w powiecie do PSL „Piast” należało 140 osób, PSL „Wyzwolenie” - 33, Stronnictwa Chłopskiego $(\mathrm{SCh})-32$. Stosunkowo liczną grupę stanowili radni bezpartyjni, tj. 122 osoby, które z pewnością jakieś preferencje polityczne miały. $\mathrm{O}$ wiele więcej danych na temat wpływów politycznych w samorządzie gminnym powiatu pińczowskiego oraz sympatii politycznych wójtów, ich zastępców, ławników oraz radnych z 19 gmin dostarczyły wybory przeprowadzone w 1934 r. Z ogólnej liczby wybranych 276 radnych do Bezpartyjnego Bloku Współpracy z Rządem (BBWR) należało 131 osób, a sympatyzowało 30 osób (razem 58,3\% sympatyków BBWR), kolejną co do wielkości grupę stanowili radni bezpartyjni, liczący 56 osób, tj. 20,3\%. Zastanawiające jest dopiero trzecie miejsce Stronnictwa Ludowego (SL), które miało w powiecie duże wpływy, a łącznie z sympatykami uzyskało tylko 13,8\%. W poprzednich wyborach z 1927 r. ludowcy osiągnęli zdecydowanie lepszy wynik. Jak podkreśla Markowski, bez analizy przemian politycznych, jakie zaszły w gminach wiejskich powiatu pińczowskiego w latach 1927-1934, nie można poprawnie określić przyczyn przewartościowania postaw politycznych wyborców. Można przypuszczać, że zniechęcenie ludności nieporadnością partii politycznych wobec kryzysu ekonomicznego, jak i nowa ordynacja wyborcza oraz duże zaangażowanie aparatu państwowego, miały wpływ na taki wynik wyborów samorządowych w 1934 r. Wybrani radni i ławnicy w powiecie pińczowskim - sympatycy BBWR - byli rolnikami, ale także nauczycielami, ziemianami i księżmi. Przedstawiciele wymienionych trzech ostatnich grup przeważnie piastowali funkcję ławników. Na uwagę zasługuje fakt, że we wspomnianych wyborach pod określeniem rolnik w spisach wyborców zostało wybranych 15 ziemian, właścicieli majątków lub zarządców majątków wywodzących się ze sfery ziemiańskiej. Na ostatnich 
wyborach, które odbyły się w 1939 r., zaciążyła sytuacja wewnętrzna państwa wywołana zagrożeniem wojennym i tym samym potrzeba konsolidacji społeczeństwa z państwem przesłoniła standardy demokratyczne (Markowski, 1999, s. 230-233).

Problematyka wpływów politycznych w samorządach terytorialnych na ziemi szydłowieckiej została omówiona przez Marka Przeniosło. I także tutaj możemy zauważyć pewne zjawiska, jak można przypuszczać charakterystyczne dla kwestii określenia wpływów politycznych w samorządzie gmin wiejskich. Również w tym przypadku autor wskazuje, że na podstawie wyborów do rad gmin wiejskich trudno jest ustalić w sposób jednoznaczny preferencje polityczne danego środowiska. Podaje przykład list bezpartyjnych, gdzie określenie orientacji politycznych jej uczestników na podstawie źródeł nie zawsze jest możliwe do ustalenia. Tak jak w przypadku powiatu pińczowskiego, tak i koneckiego pierwsze wybory samorządowe na ziemi szydłowieckiej nie dostarczają informacji o preferencjach politycznych wybranych radnych. Dopiero wybory w 1927 r. są szerzej udokumentowane i dokładniej możemy prześledzić układ sił w samorządzie gminnym na terenie całego powiatu koneckiego. Na podstawie wyników wyborów w 20 gminach na 236 mandatów PSL „Wyzwolenie” otrzymało 32 mandaty, PPS - 21, Niezależna Partia Chłopska (NPCh) - 19, PSL „Piast” - 17 (Przeniosło, 1999, s. 161-162).

Na uwagę zasługuje fakt, że najwięcej mandatów zgromadzili bezpartyjni, wśród których 82 miało poglądy lewicowe, 28 prawicowe i 26 centrowe. Powyższe dane mogą służyć za przykład jak trudno jest określić poglądy polityczne radnych bezpartyjnych, ponieważ o przypisaniu im sympatii politycznych decydowali funkcjonariusze Policji Państwowej, którzy monitorowali przebieg wyborów i na podstawie ich meldunków starostowie sporządzali sprawozdania sytuacyjne przesyłane do Urzędu Wojewódzkiego w Kielcach. Sprawą otwartą pozostaje, na podstawie jakich kryteriów przypisywano poszczególnym radnym sympatie polityczne. Także na przykładzie działalności samorządu gmin wiejskich ziemi szydłowieckiej możemy zaobserwować ewolucję polityki państwa wobec samorządu terytorialnego. Szczególnie po 1926 r. władze sanacyjne dążyły do podporzadkowania sobie działalności samorządu terytorialnego. Jako przykład mogą służyć starania starosty koneckiego w 1931 r. mające na celu odwołanie rady gminy wiejskiej Chlewiska, które posiadały podtekst polityczny. Działania tego rodzaju były podejmowane przez władze nadzorcze powiatowe i wojewódzkie na terenie całego województwa kieleckiego, a miały na celu przygotowanie gruntu pod przyszłe wybory samorządowe, w których BBWR zdominowało samorząd terytorialny na terenie województwa (APK, UWK I, sygn. 3940, s. 8-31; Przeniosło 1999, s. 164-165, 168).

W 1926 r. wojewoda kielecki przeprowadził konsultacje z podległymi mu jednostkami administracji państwowej, pozwalając prześledzić także opinie admini- 
stracji powiatowej na temat kwestii politycznych w tym ordynacji wyborczych. Ogólnie dominował pogląd o potrzebie apolityczności samorządu terytorialnego. Powszechna była obawa w środowiskach wiejskich działaczy samorządowych, że osiągnięty kompromis w sprawie przyszłej ustawy samorządowej jest raczej układem politycznym, który w małym stopniu odpowiadał realnym stosunkom panującym w gminach wiejskich. Wynikało to m.in. z propozycji głosowania na listy zbiorowe kandydatów do samorządu gminnego. Samorządowcy uważali, że takie rozwiązanie uczyni z samorządu arenę walki politycznej, która byłaby zabójcza dla idei samorządności. Co jest niezwykle interesujące, autorzy wniosków zaznaczali, że powyższy sąd nie wynikał z chęci przypodobania się władzy, z powodu ogólnej krytyki tzw. partyjniactwa. Ich zadaniem doświadczenia wynikające z codziennej pracy potwierdzały, że tam, gdzie było więcej polityki w pracy samorządu wiejskiego, to zdecydowanie mniej koncentrowano się na pracy gospodarczej i kulturalnej. Dodatkowo stronnictwa polityczne, zdaniem samorządowców, nie potrafiły zawierać kompromisów służących sprawom nadrzędnym dla gmin wiejskich. Jeżeli danemu stronnictwu nie udało się przeprowadzić własnego projektu to robiło wszystko, aby storpedować konkurencyjny projekt, nawet wtedy, gdy był on korzystny dla środowiska wiejskiego. $Z$ tego powodu, zdaniem przedstawicieli samorządów wiejskich, najważniejsze sprawy dla wielu gmin nie mogły się doczekać realizacji (APK, UWK I, sygn. 6915, s. 9; sygn. 3934, s. 76).

W wielu opiniach przedstawicieli środowisk samorządowych pojawiał się postulat głosowania na nazwiska konkretnych kandydatów, co byłoby najbardziej czytelne i sprawiedliwe dla mieszkańców wsi. Jednocześnie podkreślano, że głosowanie na listy było rozwiązaniem mało przejrzystym, stwarzającym możliwości nadużyć, wypaczając tym samym prawo swobodnego wyboru. Przy tej okazji pojawiały się pytania o to, kto będzie układał listy kandydatów, a nieodosobnione były głosy, że cieszący się największym zaufaniem i szacunkiem mieszkańcy wsi będą się uchylać od uczestnictwa w ich układaniu. Działacze samorządowi przewidywali, że może to być powodem braku w wielu miejscowościach zgłoszonych w terminie list kandydatów. Obawiano się jednocześnie, że inicjatywę w ich układaniu przejmą jednostki o wątpliwych zaletach moralnych, próbujące przy tej okazji załatwić swoje prywatne sprawy. Skutkiem tego doprowadzi to do zniechęcenia mieszkańców wsi do wyborów i tym samym powstaną samorządy nieposiadające zaufania społecznego, niezdolne do działania. Postulowano, aby każda wieś wchodząca w skład gminy zbiorowej była reprezentowana w radzie gminnej. Do tych wniosków dołączono szczegółowe propozycje organizacji zgłaszania kandydatów oraz przeprowadzania ich wyboru (UWK I, sygn. 3934, s. 77). W praktyce władze państwowe systematycznie zwiększały kontrolę nad działalnością samorządu 
terytorialnego, m.in. przez wpływ administracji terenowej na tworzenie okręgów wyborczych. W 1933 r. Ministerstwo Spraw Wewnętrznych (MSW) w poufnym dokumencie skierowanym do wojewodów województw centralnych i wschodnich przesłało opracowany przez siebie regulamin wyborczy do rad gromadzkich. Według wspomnianego regulaminu decyzja co do podziału obszaru gromady na okręgi wyborcze i podziału mandatów między okręgi wyborcze, od której nie było odwołania, należała do starosty (APK, UWK I, sygn. 3934, s. 508-509, 518).

Dla ruchu ludowego samorząd wiejski był naturalnym środowiskiem działania. Działacze, tak jak m.in. PSL „Wyzwolenie”, jak i PSL „Piast”, uważali, że opanowanie samorządu terytorialnego jest kluczowe dla realizacji celów politycznych. Ludowcy uważali, że ten, kto rządzi w gminie, ten rządzi w państwie i wielu z nich mimo pełnienia najwyższych urzędów państwowych nie zrzekało się funkcji w samorządach, jak np. Wincenty Witos. Mimo braku dokładnych danych dotyczących pierwszych przeprowadzonych w 1919 r. wyborów do rad gminnych i powiatowych, można założyć, że na terenie województwa kieleckiego PSL „Wyzwolenie” zdobyło silne wpływy. Postulaty programowe tego stronnictwa dotyczące miejsca i roli samorządu wiejskiego w państwie polskim były radykalne i dotyczyły m.in. zapewnienia samorządowi szerokiej autonomii i możliwości kontroli urzędników przez miejscową ludność, sprawnego załatwiania spraw lokalnych, ukrócenia nadużyć i korupcji w urzędach. Samorząd miał stanowić przeciwwagę dla biurokracji państwowej i realizować idee ludowładztwa oraz niezależnego od administracji państwa (starostów) wyboru przez ogół gminy rad gminnych, wójtów, sołtysów i sekretarzy gminnych (Jachymek, 1989, s. 488-499).

Wydłużenie kadencji wybranych w 1919 r. samorządów gmin wiejskich związane było z toczącymi się pracami nad nową ustawą samorządową, która miała przede wszystkim za zadanie doprowadzić do unifikacji ustroju samorządu terytorialnego na obszarze całego kraju. Wola przeprowadzenia wyborów według nowych unormowań prawnych była powodem przedłużenia kadencji działających samorządów, a jednym z inicjatorów tej decyzji było PSL „Piast”, którego działacze aktywnie uczestniczyli w pracach nad nową ustawą, tak jak i PSL „Wyzwolenie”. Decyzja o przeprowadzeniu wyborów samorządowych w 1927 r. zapadła już w nowej rzeczywistości politycznej. Nie bez znaczenia był również kontekst polityczny decyzji o zarządzeniu wyborów samorządowych, sondaż nastrojów politycznych przed zbliżającymi się wyborami parlamentarnymi. W wyniku wyborów w 283 gminach województwa kieleckiego PSL „Piast” uzyskało 861 mandatów przed wyborami 914, PSL „Wyzwolenie” 614 - przed wyborami 599, ZLN 529 przed wyborami 666, Stronnictwo Chrześcijańsko-Narodowe (SChN) 515 - przed wyborami 364. Na 292 wybranych wójtów 66 było członkami BBWR, 40 - PSL „Piast”, 22 - PSL „Wyzwolenie”, 22 - SChN i 16 - ZLN (Jachymek, 1989, s. 503). 


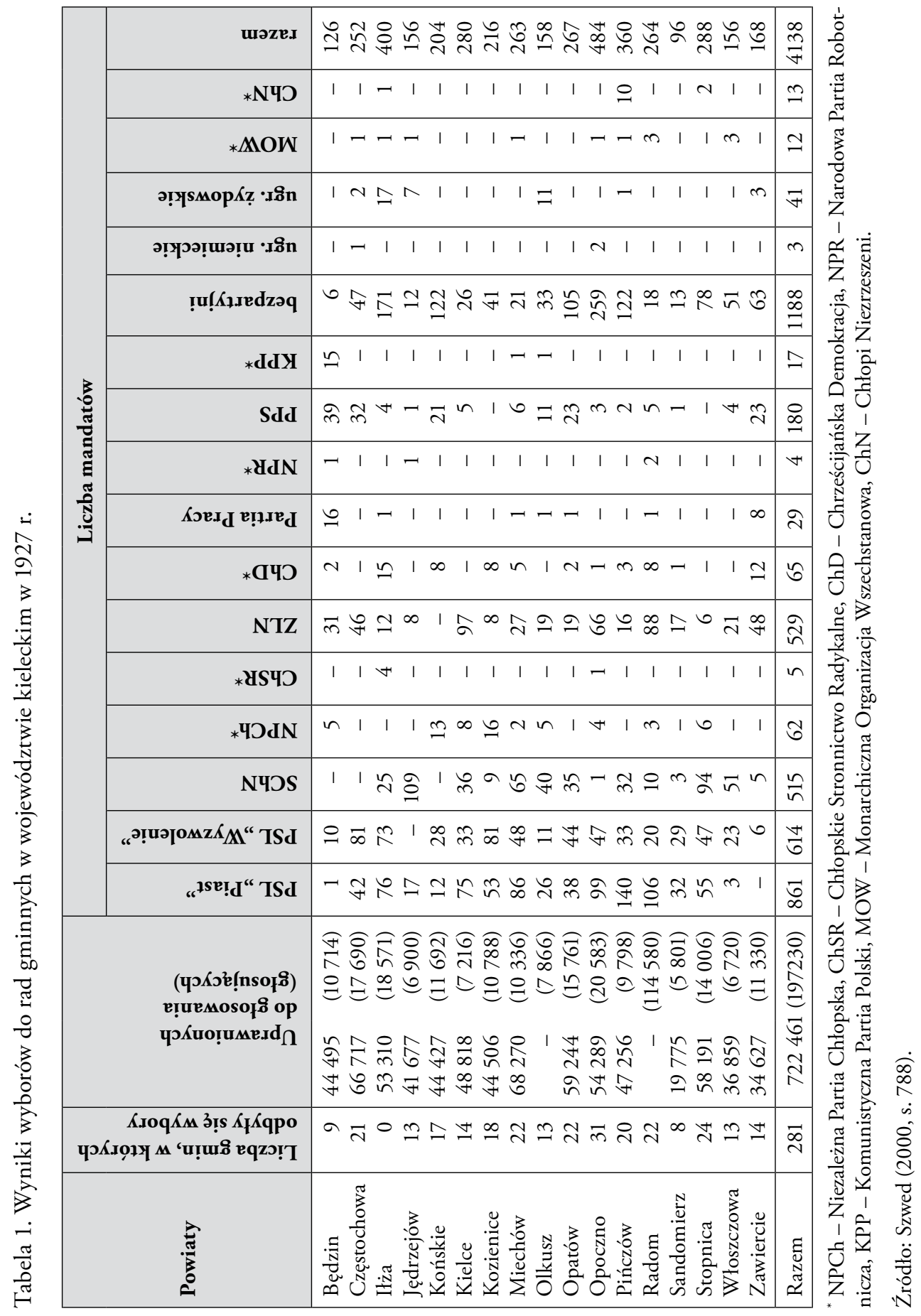


Władze państwowe dokładnie monitorowały sytuację polityczną w samorządzie terytorialnym, w tym gmin wiejskich. Po wyborach z 1927 r. starostowie z terenu województwa kieleckiego w nadsyłanych do urzędu wojewódzkiego sprawozdaniach ocenili przebieg wyborów, ich wyniki, jak również stopień zaangażowania społeczeństwa w wyborach. Urząd wojewódzki oczekiwał od starostów informacji na temat m.in.: zaangażowanych w akcję wyborczą stronnictw politycznych; sojuszy wyborczych; stopniu odzwierciedlenia w wyłonionym układzie sił politycznych sytuacji politycznej na danym terenie; stosunku w czasie kampanii wyborczej chrześcijańskich stronnictw politycznych i ogółu ludności polskiej do żydowskich ugrupowań biorących udział w wyborach; dominujących haseł wyborczych - politycznych bądź gospodarczych; udziale w wyborach m.in. duchowieństwa, ziemiaństwa, nauczycieli oraz ich wpływu na akcje, kampanię i wyniki wyborów. Starostowie w swoich sprawozdaniach przesyłanych do urzędu wojewódzkiego wskazywali na umiarkowane zainteresowanie wyborami w gminach wiejskich i dość duże różnice frekwencji w poszczególnych gminach. Jako przykład może służyć powiat będziński, zróżnicowany (4 gminy przemysłowe), gdzie frekwencja głosujących w gminach wiejskich wyniosła od 35\% do 65\%. Jednie w gminie olkusko-siewierskiej frekwencja wyniosła $20 \%$, zdaniem starosty z powodu rozległości gminy i znacznej odległości do punktu wyborczego $(16 \mathrm{~km})$. Jednak frekwencja w wyborach do rad gminnych, jakie odbyły się w 1927 r. na terenie województwa kieleckiego była niska, np. w powiecie kieleckim wyniosła 15,3\% (APK, UWK I, sygn. 2643, s. 14, 15, 54-58, 89).

$\mathrm{Na}$ uwagę zasługuje nikły udział w wyborach kobiet, co zostało podkreślone przez starostów, jedyne wyjątki to nauczycielki z wiejskich szkół. Ugrupowania polityczne do wyborów rad gminnych szły przeważnie pod hasłami gospodarczymi, ale były także powiaty, jak m.in. Miechowski, gdzie hasła polityczne zdominowały kampanię wyborczą. W sprawozdaniach starostowie podkreślali, że w wyborach do rad gmin wiejskich, gdzie dominowały hasła gospodarcze głosowano przeważnie na osoby, a nie na konkretne ugrupowania polityczne. Dochodziło często do rywalizacji między kandydatami wywodzącymi się z tych samych ugrupowań politycznych. Zdaniem starostów z tego powodu wyniki wyborów do rad gmin wiejskich nie były w pełni odbiciem układu sił politycznych. Ogólnie nie odnotowano napięć w kampanii wyborczej między ludnością polską a żydowską z tego względu, że Żydzi w gminach wiejskich nie odgrywali większej roli. Jako przykład podano, że w gminach wiejskich powiatu miechowskiego kierowano się "tradycją” mówiącą, że Żydzi w radzie gminnej nie zasiadali i zasiadać nie powinni”. Wskazano na przeważającą bierność duchowieństwa oraz ziemiaństwa w kampanii wyborczej i nieco większą aktywność nauczycieli. Starosta olkuski w swoim raporcie odniósł 
się krytycznie do postawy duchowieństwa, ziemiaństwa i inteligencji wobec samorządu gmin wiejskich, formułując opinię, że „te sfery” jeszcze do dziś nie zdają sobie sprawy z nowego ustroju demokratycznego, separują się od ogółu wyborców, a tylko w drodze protestów do starostwa ustnych lub pisemnych starają się przeciwdziałać zatwierdzaniu niewygodnych im kandydatów, zamiast czynnie angażować się w akcje wyborcze (APK, UWK I, sygn. 2079, s. 59; sygn. 2643, s. 90, 127-132, $167,172-174)$.

Administracja państwowa przez wydziały powiatowe sprawujące nadzór nad samorządem gmin wiejskich miała wpływ na obsadę stanowisk wójtów oraz mogła wywierać naciski na pracę rad gminnych. Przeprowadzane kontrole działalności wójtów i rad w dobiegającej końca kadencji samorządu wiejskiego zapoczątkowanej w 1927 r. dotyczyły całokształtu pracy instytucji i organów samorządu wiejskiego. Jak informowano, „z powodów nienależytego i niezgodnego z przepisami prawa pełnieniem obowiązków" na skutek przeprowadzonych kontroli odwołano w 8 powiatach 17 wójtów i rozwiązano rady w 5 gminach. W ocenie Urzędu Wojewódzkiego w Kielcach samorząd gmin wiejskich za lata 1927-1933 wypełnił swoje zadania. Podkreślono, że większość niedomagań w pracy samorządu wiejskiego wynikało z dużej liczby zadań, jakie na nim spoczywały, i ograniczonych środków na ich realizację. W ocenie władz administracyjnych powodem takiego stanu rzeczy był kryzys gospodarczy wymuszający oszczędności, w tym redukcję etatów urzędników samorządowych. Ostra walka polityczna w kraju miała miejsce również $\mathrm{w}$ samorządzie terytorialnym. Władze sanacyjne wykorzystywały nastroje antypartyjne społeczeństwa do tworzenia samorządów apolitycznych, a w rzeczywistości prorządowych. Propaganda, jak również kontrowersyjne działania starostów ingerujących $\mathrm{w}$ tok przygotowań i kampanie wyborcze, przyniosły obozowi władzy sukces. W wyborach do rad gromadzkich rozpoczętych w województwie kieleckim pod koniec 1933 r., a zakończonych w 1934 r. na ogólną liczbę 42066 radnych do rad gromadzkich BBWR zdobyło 24028 mandatów (57,1\%), SL 6764 (16,1\%). W radach gminnych na 4507 mandatów BBWR miało 2776 (61,5\%), a SL 457 (10,2\%) (APKat, SPZaw, sygn. 878, s. 186-187; J. Jachymek, 1989, s. 508-509).

Trudno jest określić motywację (polityczną czy merytoryczną) podejmowanych przez starostów niektórych decyzji personalnych. Za przykład może służyć sprawa zatwierdzania przez starostów kandydatów na sołtysów. Pełnienie funkcji sołtysa tak przed 1914 r., jak i po odzyskaniu niepodległości, wiązało się ze znacznymi obciążeniami osób pełniących te funkcje przy jednoczesnym skromnym ich uposażeniu. Podkreślono, że po 1918 r. sołtysom przybyło dużo nowych dodatkowych obowiązków, co stanowiło poważną przeszkodę w prowadzeniu własnego gospo- 


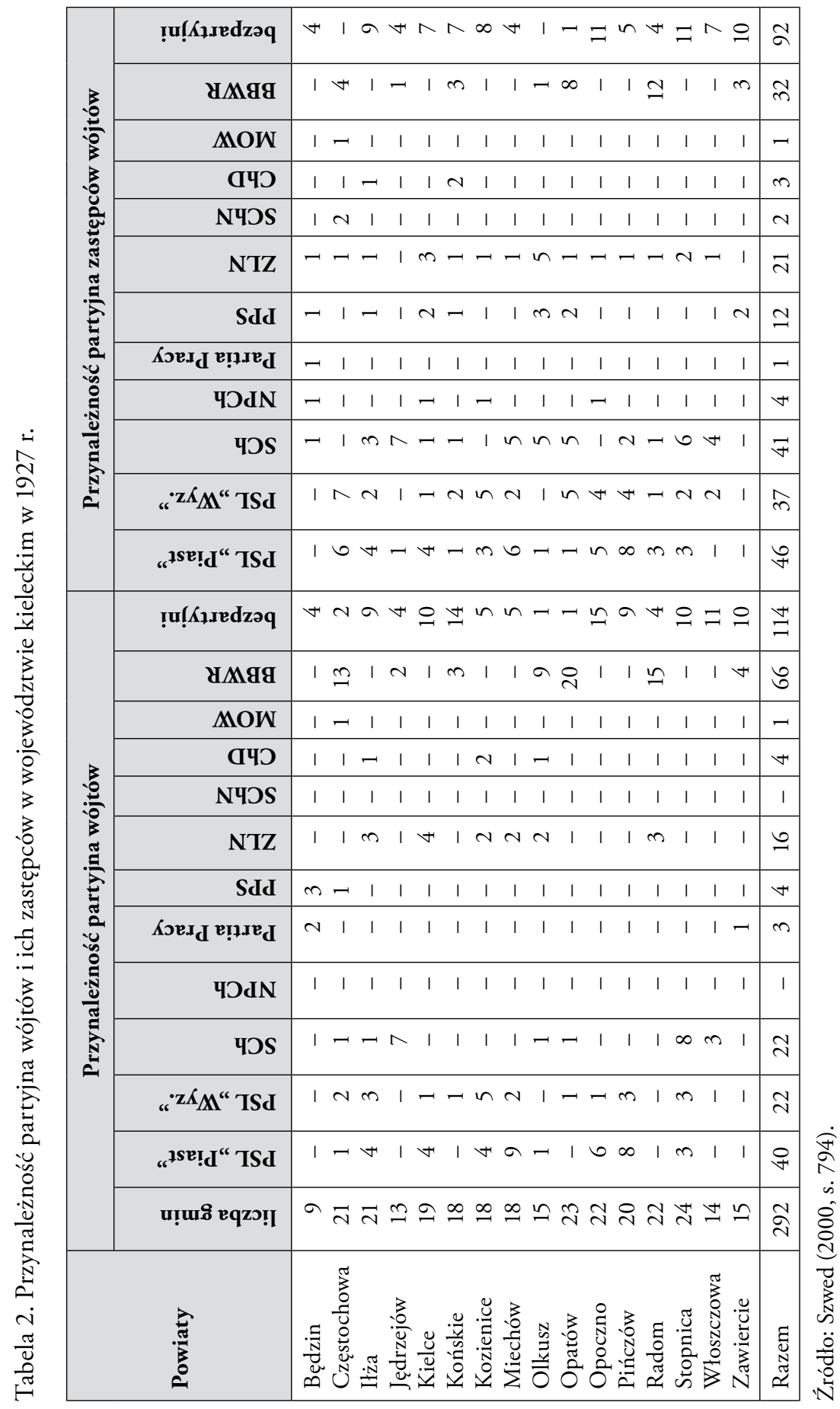


darstwa. Mimo to dotychczasowi sołtysi w powiecie kieleckim nie rezygnowali ze swoich funkcji i ubiegali się o wybór na kolejną kadencję. Wydziały powiatowe, analizując przyczyny „popularności” funkcji sołtysa, wiązało ją z licznymi nadużyciami finansowymi popełnianymi przez urzędujących sołtysów. Kontrole wykazywały, że wielu z nich przetrzymywało lub przywłaszczało środki pieniężne pochodzące z pobieranych podatków skarbowych i danin komunalnych. W związku z zaistniałą sytuacją władze nadzorcze podjęły szereg środków zapobiegawczych, jak również zwróciły się do starostów powiatowych o niezatwierdzanie na urząd sołtysa osób, które już te funkcję sprawowały lub przy braku kandydatów spełniających wymagania nie zatwierdzać osób, które sprawowałby ten urząd kadencja po kadencji (APK, SPK, sygn. 2724, s. 1, 14, 30, 31).

Tabela 3. Wyniki wyborów do rad gromadzkich w województwie kieleckim w 1933 r.

\begin{tabular}{|l|r|r|r|r|r|r|r|}
\hline & \multirow{2}{*}{$\begin{array}{c}\text { Liczba } \\
\text { gromad }\end{array}$} & \multicolumn{7}{|c|}{ Liczba mandatów } \\
\cline { 3 - 8 } & & ogólna & BBWR & bezpartyjni & \multicolumn{1}{|c|}{ SL } & ChSR & \multicolumn{1}{|c|}{ SN* } \\
\hline Będzin & 61 & 1148 & 615 & 440 & 35 & - & 18 \\
Częstochowa & 263 & 3683 & 2544 & 167 & 531 & 29 & 216 \\
Jędrzejów & 189 & 2304 & 808 & - & 993 & - & 25 \\
Kielce & 246 & 3478 & 1705 & 1746 & 20 & - & 7 \\
Końskie & 300 & 3416 & 2747 & - & 290 & - & 185 \\
Kozienice & 307 & 3434 & 1615 & - & 592 & - & 118 \\
Miechów & 285 & 3764 & 2190 & - & 1236 & - & - \\
Opatów & 283 & 3717 & 1707 & 672 & 1051 & - & 96 \\
Opoczno & 341 & 3310 & 3040 & - & 69 & - & 188 \\
Pińczów & 263 & 3008 & 1228 & 742 & 1118 & - & - \\
Sandomierz & 245 & 3048 & 1029 & 1629 & 170 & - & - \\
Stopnica & 283 & 3512 & 1320 & 1749 & 148 & 258 & 18 \\
Włoszczowa & 188 & 2216 & 1596 & - & 498 & - & 92 \\
Zawiercie & 134 & 1948 & 1884 & - & 13 & - & 8 \\
\hline Razem & 3388 & 42066 & 24028 & 7145 & 6764 & 287 & 971 \\
\hline
\end{tabular}

"SN - Stronnictwo Narodowe.

Źródło: Szwed (2000, s. 807).

Jako przykład problemów związanych z analizą wpływów politycznych mogą świadczyć zalecenia MSW dla urzędów wojewódzkich odnośnie do właściwego sporządzania kwartalnych zestawień odzwierciedlających układ sił politycznych i narodowościowych w samorządach. MSW w związku z niedokładanymi sprawozdaniami sporządzanymi przez urzędy wojewódzkie (na podstawie raportów starostów) opracowało ujednolicone formularze zestawień, które za pośrednictwem wo- 
jewodów skierowane były dla starostów powiatowych. W poufnych zaleceniach dla wojewodów MSW podkreślało wagę prawidłowego nadzoru urzędów wojewódzkich nad sporządzanymi przez starostwa zestawieniami i zalecało w tym temacie współpracę wydziałów samorządowych z wydziałami bezpieczeństwa publicznego urzędów wojewódzkich. W 1933 r. wydział bezpieczeństwa publicznego Urzędu Wojewódzkiego w Kielcach w piśmie do starostów powiatowych i grodzkich negatywnie ocenił nadesłane przez nich zestawienia. Podkreślono, że wiele sprawozdań zostało sporządzonych „chaotycznie i niestarannie”, z wieloma błędami rachunkowymi itp. Jak można przypuszczać, wymóg terminowego nadsyłania zestawień przez urzędy wojewódzkie do MSW wobec powyższych problemów mógł wpływać na ich wiarygodność (APK, UWK I, sygn. 2652, s. 1, 3, 5, 105, 161, 162; SPK, sygn. 1-11; APKat, SPOlk, sygn. 18, s. 86, 87, 88).

Tabela 4. Wyniki wyborów do rad gminnych w województwie kieleckim w 1934 r.

\begin{tabular}{|c|c|c|c|c|c|c|c|c|c|}
\hline \multirow[b]{2}{*}{ Powiat } & \multirow[b]{2}{*}{ 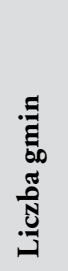 } & \multicolumn{8}{|c|}{ Liczba mandatów } \\
\hline & & $\frac{\Xi}{0}$ & 点 & 芯 & Z & 옹 & 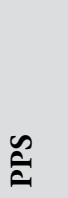 & $\ddot{\omega}$ & 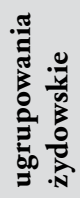 \\
\hline Będzin & 9 & 160 & 115 & 30 & 4 & - & 5 & 6 & - \\
\hline Częstochowa & 21 & 352 & 293 & 3 & 14 & 3 & 12 & 26 & 1 \\
\hline Iłża & 21 & 308 & 216 & 29 & - & - & - & 54 & 5 \\
\hline Jędrzejów & 13 & 211 & 141 & 4 & 12 & - & - & 51 & 3 \\
\hline Kielce & 19 & 312 & 113 & 150 & 9 & 5 & 4 & 28 & 3 \\
\hline Końskie & 18 & 292 & 189 & - & 21 & - & 14 & 29 & - \\
\hline Kozienice & 19 & 296 & 183 & 26 & 5 & - & - & 82 & - \\
\hline Miechów & 24 & 364 & - & - & - & - & - & - & - \\
\hline Olkusz & 14 & 240 & 148 & 38 & 3 & 3 & 9 & 38 & 1 \\
\hline Opatów & 23 & 356 & 260 & 24 & 9 & 2 & 2 & 55 & 4 \\
\hline Opoczno & 22 & 324 & 302 & - & 14 & - & - & 1 & 7 \\
\hline Pińczów & 20 & 296 & 178 & 69 & 7 & - & 1 & 39 & 3 \\
\hline Radom & 22 & 344 & 267 & - & 43 & - & 2 & 32 & - \\
\hline Sandomierz & 14 & 228 & 218 & - & - & - & - & 4 & 6 \\
\hline Stopnica & - & - & - & - & - & - & - & - & - \\
\hline Włoszczowa & 14 & 200 & - & - & - & - & - & - & - \\
\hline Zawiercie & 15 & 224 & 153 & 36 & 11 & 2 & 7 & 12 & 3 \\
\hline Razem & 288 & 4507 & 2776 & 409 & 152 & 15 & 56 & 457 & 36 \\
\hline
\end{tabular}

Źródło: APK, SPK, sygn. 3005, s. 33, 33a; Szwed (2000, s. 808). 
Wybory sołtysów i ich zastępców przeprowadzone w grudniu 1936 i styczniu 1937 r. na terenie województwa kieleckiego w większości gromad przebiegły bez żadnych zakłóceń i dały zdecydowaną przewagę kandydatom prorządowym, którzy stanowili $86 \%$ wszystkich wybranych sołtysów i ich zastępców w województwie. Drugą co do wielkości grupę wybranych sołtysów i ich zastępców stanowili bezpartyjni $(22,8 \%)$, a kandydaci SL zajęli trzecie miejsce $(7,6 \%)$. Uroczyste zaprzysiężenie nowo wybranych sołtysów i ich zastępców nastąpiło w marcu 1937 r. (APK, SPK, sygn. 257, s. 1, 35; SPK, sygn. 256, s. 3, 5).

Tabela 5. Wynik wyborów sołtysów i ich zastępców w województwie kieleckim w grudniu 1936 i styczniu 1937 r. (członkowie/zwolennicy)

\begin{tabular}{|l|r|r|r|r|r|r|r|r|}
\hline \multicolumn{1}{|c|}{ Powiat } & $\begin{array}{c}\text { Obóz } \\
\text { prorzą- } \\
\text {-dowy }\end{array}$ & \multicolumn{1}{c|}{ SN } & \multicolumn{1}{c|}{ SL } & PPS & $\begin{array}{c}\text { KPP } \\
\text { i SCh }\end{array}$ & ChD & ChSR & $\begin{array}{c}\text { Bezpar- } \\
\text { tyjni }\end{array}$ \\
\hline Będziński & 60 & $-/ 3$ & $2 / 4$ & $2 / 7$ & $1 /-$ & $-/-$ & $-/-$ & 36 \\
Częstochowski & 138 & $31 / 27$ & $95 / 14$ & $13 / 8$ & $-/-$ & $6 / 2$ & $-/-$ & 168 \\
Iłżecki & 257 & $-/ 25$ & $17 / 191$ & $-/ 8$ & $3 /-$ & $-/-$ & $-/-$ & 53 \\
Jędrzejowski & 120 & $18 / 29$ & $34 / 36$ & $1 / 7$ & $-/-$ & $-/-$ & $-/-$ & 82 \\
Kielecki & 339 & $1 / 35$ & $3 / 61$ & $1 / 15$ & $1 /-$ & $-/-$ & $-/-$ & - \\
Konecki & 414 & $17 / 25$ & $11 / 24$ & $12 / 17$ & $12 /-$ & $-/-$ & $-/-$ & 334 \\
Kozienicki & 98 & $-/ 22$ & $37 / 155$ & $-/-$ & $-/-$ & $-/-$ & $-/-$ & 226 \\
Miechowski & 145 & $19 /-$ & $151 / 26$ & $-/-$ & $-/-$ & $-/-$ & $-/-$ & 144 \\
Olkuski & 107 & $-/ 10$ & $9 / 145$ & $-/ 22$ & $-/-$ & $-/ 23$ & $7 / 6$ & 47 \\
Opatowski & 272 & $4 / 20$ & $11 / 156$ & $-/ 30$ & $-/-$ & $-/ 5$ & $-/-$ & 79 \\
Opoczyński & 127 & $76 / 55$ & $6 / 22$ & $2 /-$ & $-/-$ & $-/-$ & $-/-$ & 336 \\
Pińczowski & 193 & $-/ 13$ & $40 / 160$ & $-/-$ & $-/-$ & $-/-$ & $-/-$ & 41 \\
Radomski & 146 & $72 / 52$ & $41 / 21$ & $4 /-$ & $-/-$ & $-/-$ & $-/-$ & 284 \\
Sandomierski & 131 & $-/-$ & $-/-$ & $-/-$ & $15 /-$ & $-/-$ & $-/-$ & - \\
Stopnicki & 106 & $3 / 2$ & $36 / 61$ & $-/-$ & $4 /-$ & $-/-$ & $169 / 15$ & 98 \\
Włoszczowski & 83 & $6 / 73$ & $26 / 122$ & $-/ 1$ & $-/-$ & $-/-$ & $-/-$ & 8 \\
Zawierciański & 77 & $-/ 1$ & $4 / 16$ & $-/ 14$ & $1 /-$ & $-/-$ & $-/-$ & 143 \\
\hline Razem & 2816 & $247 / 57$ & $595 / 156$ & $35 / 102$ & $37 /-$ & $6 / 28$ & $176 / 21$ & 1779 \\
& $86 \%$ & $3,1 \% /$ & $7,6 \% /$ & $0,4 \% /$ & $0,5 \% /-$ & $0,1 \% /$ & $2,2 \% /$ & $22,8 \%$ \\
& & $5,1 \%$ & $26 \%$ & $1,3 \%$ & & $0,4 \%$ & $0,3 \%$ & \\
\hline
\end{tabular}

Źródło: APK, SPK, sygn. 257, s. 1.

Przygotowywania do wyborów samorządowych w 1939 r. przebiegały już w duchu nowych przepisów, ale także w atmosferze dużego napięcia międzynarodowego. Poczucie zagrożenia wymuszało konsolidację wszystkich środowisk i ugrupowań politycznych wokół polityki władz państwowych. Znalazło to wyraz w masowym uczestnictwie różnego rodzaju środowisk społecznych i politycznych 
w pracach Obozu Zjednoczenia Narodowego (OZN), którego kandydaci ubiegali się o mandaty w samorządzie terytorialnym. Mimo że sytuacja międzynarodowa i wewnętrzna ulegała zaostrzeniu, SW przystąiło do przygotowywania wyborów samorządowych. We wrześniu 1938 r. minister MSW przesłał wojewodom, starostom, przewodniczącym wydziałów powiatowych, zarządom miejskim i zarządom gmin wiejskich zasadnicze wytyczne w sprawie wyborów samorządowych, jak i instrukcje dla organów gminnych i komisji wyborczych w sprawie wyboru radnych gromadzkich i gminnych. W wytycznych wyszczególniono 5 zagadnień, na które wojewodowie, starostowie i przełożeni gmin wiejskich i miejskich mieli zwrócić uwagę. Pierwsze dotyczyło swobodnego wykonywania praw wyborczych sprowadzającego się do niedopuszczenia w wyborach niewłaściwej ingerencji władz administracyjnych, jak i presji „czynników niepowołanych”. Po drugie należało zagwarantować rzetelność aktu wyborczego przez dokładne i bezstronne wywiązanie się ze swoich obowiązków członków komisji wyborczych. Trzecie zagadnienie dotyczyło protestów wyborczych, tzn. procedury postępowania. Zalecono uświadomić wyborców, że wnoszenie bezpodstawnych protestów przynosi szkodę samorządowi, opóźniając termin wyborów do organów samorządu wyższego stopnia. Kolejne zalecenia dotyczyły składu komisji wyborczych, do których powinny wchodzić osoby o nieposzlakowanej opinii, cieszące się powszechnym szacunkiem w danym środowisku. Ostatnie zagadnienie dotyczyło konferencji instrukcyjnych dla organów gminnych i wyborczych, na których miano omawiać przepisy ustawy wyborczej z wydanymi do niej wskazówkami (APCz, SPCz, sygn. 636, s. 52-79; APK, SPK, sygn. 219, s. 2, 10, 16, 17).

Na początku 1939 r. wojewoda kielecki informował MSW, że na terenie województwa kieleckiego na 313 gmin wiejskich zarządzono i przeprowadzono wybory w 305 gminach. W 4 gminach kadencja rad upływała dopiero w 1941 r., a w jednej w 1943 r., w 3 wybory wyznaczono na sierpień 1939 r. Wybory do rad gromadzkich na terenie województwa kieleckiego, jeżeli chodzi o ugrupowania polityczne, wygrał OZN, a kolejne miejsca zajęły SL i SN. Wspomniane ugrupowania prowadziły aktywną kampanię wyborczą, urządzając zebrania, konferencje i odprawy. Sukces OZN był podyktowany w dużej mierze tym, że udało się mu pozyskać radnych niezdeklarowanych politycznie, którzy stanowili w wybranych radach gromadzkich znaczący odsetek (APK, UWK I, sygn. 3290, s. 2, 41; UWK I, sygn. 3934, s. 750, 752, 771-778). 
Tabela 6. Wyniki wyborów do rad gminnych w województwie kieleckim w 1939 r.

\begin{tabular}{|c|c|c|c|c|c|c|c|c|}
\hline \multirow[b]{2}{*}{ Powiat } & \multicolumn{8}{|c|}{ Liczba radnych } \\
\hline & $\frac{\tilde{0}}{\stackrel{0}{0}}$ & Zু & 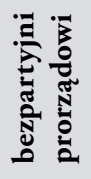 & 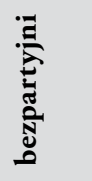 & Z & ๘ & 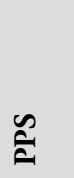 & 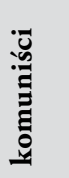 \\
\hline Będzin & 164 & 38 & 43 & 34 & 3 & 5 & 36 & 5 \\
\hline Częstochowa & 352 & 110 & 110 & 79 & 16 & 23 & 14 & - \\
\hline Iłża & 328 & 183 & 59 & 46 & - & 39 & 1 & - \\
\hline Jędrzejów & 212 & 101 & 39 & 46 & 4 & 22 & - & - \\
\hline Kielce & 304 & 188 & 55 & 8 & 17 & 29 & 7 & - \\
\hline Końskie & 284 & 64 & 131 & 21 & 37 & 11 & 18 & 2 \\
\hline Kozienice & 272 & 113 & 76 & 56 & 3 & 24 & - & - \\
\hline Miechów & 360 & 133 & 87 & 14 & 18 & 105 & 1 & - \\
\hline Opoczno & 328 & 130 & 68 & 14 & 103 & 13 & - & - \\
\hline Opatów & 324 & 162 & 50 & 21 & 9 & 68 & 14 & - \\
\hline Olkusz & 228 & 52 & 81 & 20 & 14 & 50 & - & 1 \\
\hline Pińczów & 296 & 152 & 30 & 61 & 4 & 47 & 10 & - \\
\hline Radom & 344 & 127 & 93 & 36 & 55 & 31 & 2 & - \\
\hline Sandomierz & 232 & 143 & 50 & 27 & 2 & 9 & 2 & - \\
\hline Stopnica & 372 & 126 & 95 & 30 & 7 & 113 & 1 & - \\
\hline Włoszczowa & 216 & 84 & 71 & 22 & 6 & 33 & 1 & - \\
\hline Zawiercie & 232 & 119 & 29 & 41 & 10 & 18 & 14 & 1 \\
\hline Razem & 4848 & 2025 & 1167 & 578 & 308 & 640 & 121 & 9 \\
\hline
\end{tabular}

Źródło: APK, UWK I, sygn. 3290, s. 43; Szwed (2000, s. 824).

Po odzyskaniu niepodległości mieszkańcy wsi województwa kieleckiego z działalnością samorządu gminnego wiązali duże nadzieje, a szczególnie działacze ruchu chłopskiego. Jak już wspomniano, uwarunkowania polityczne, ustrojowe i gospodarcze nie sprzyjały umocnieniu się przekonania wśród mieszkańców wsi o doniosłej roli samorządu gminnego. Od samego powołania samorząd gminny borykał się z zasadniczymi problemami związanymi z ustrojem gminy, jak i małym zainteresowaniem mieszkańców wsi województwa kieleckiego uczestnictwem w zebraniach gminnych. W celu uniknięcia paraliżu decyzyjnego organizatorzy zebrań dopuszczali się nadużyć proceduralnych, co było niezgodne z duchem samorządności i sankcjonowało działania niezgodne z obowiązującym prawem. Niedotrzymywanie procedur demokratycznych przy wyłanianiu rad gminnych skutkowało brakiem zaufania członków gmin wiejskich do swoich rad i jego organów, o czym świadczyły kierowane do organów nadzorczych protesty mieszkańców. Również 
wynikające z okoliczności politycznych zbyt długie kadencje wybranych rad spotykały się z dezaprobatą społeczności gminnej. Doniosłe znaczenie dla funkcjonowania samorządu gminnego miała polityka państwa po 1926 r., która zmierzała do uzyskania pełnej kontroli nad samorządem terytorialnym i wyznaczenia mu roli jednego z elementów administracji państwowej. Wynikające z tego powodu zwiększenie liczby zadań samorządu gminnego, które nie miało wiele wspólnego z gospodarką samorządową, wpływało niekorzystnie na stopień zaangażowania mieszkańców wsi w prace samorządowe.

\section{Bibliografia:}

Brodowska, H. (1989). Gmina wiejska i jej samorząd w doświadczeniach działaczy chłopskich (1918-1939). W: H. Brodowska (red.). Gmina wiejska i jej samorząd (s. 433-448). Warszawa: Ludowa Spółdzielnia Wydawnicza.

Jachymek, J. (1989). Ruch ludowy a gminny samorząd wiejski w latach 1918-1939. W: H. Brodowska (red.). Gmina wiejska i jej samorzad (s. 488-509). Warszawa: Ludowa Spółdzielnia Wydawnicza.

Markowski, M.B. (1999). Samorząd terytorialny w Pińczowie do 1939 r. W: R. Kołodziejczyk, M.B. Markowski (red.). Spoteczności matomiasteczkowe w regionie świętokrzyskim $(X I X-X X$ w.) (s. 225-245). Kielce: Kieleckie Towarzystwo Naukowe.

Przeniosło, M. (2009). Preferencje polityczne mieszkańców ziemi szydłowieckiej w okresie II Rzeczypospolitej. W: M. Przeniosło (red.). Z dziejów powiatu szydtowieckiego (s. 149-173). Szydłowiec: Drukarnia Panzet.

Szwed, R. (2000). Samorząd terytorialny w Polsce w latach 1918-1939. Wybór materiatów źródtowych. Częstochowa: Wydawnictwo Wyższej Szkoły Pedagogicznej w Częstochowie.

\section{Źródła archiwalne:}

Archiwum Państwowe w Kielcach:

- zespół Urzędu Wojewódzkiego Kieleckiego I, sygn. 2079, 2643, 2652, 3290, 3934, 3940, 6915.

- zespół Starostwa Powiatowego Kieleckiego, sygn. 1, 2, 3, 4, 5, 6, 7, 8, 9, 10, 11, 256, 257, 219, 2724.

Archiwum Państwowe w Katowicach:

- zespół Starostwa Powiatowego Zawierciańskiego, sygn. 878.

- zespół Starostwa Powiatowego Olkuskiego, sygn. 18.

Archiwum Państwowe w Częstochowie:

- zespół Starostwa Powiatowego Częstochowskiego, sygn. 636. 